\title{
Vertisols properties and classification in relation to parent material differentiation near Strzelin (SW Poland)
}

\begin{abstract}
Vertisols are characterized by high content of clay fraction that affects their specific morphological and physical features. The shrink-swell phenomena of clayey materials under specific moisture regime cause formation of cracks, wedge-shaped structural aggregates and slickensides on aggregate surfaces. It was formerly believed that these soils can be found only in tropical/ subtropical zones, thus Vertisols have not been expected to form under temperate climate of Central Europe. As a result, Vertisols are insufficiently recognized and documented on soil maps in Poland, including the Lower Silesia region. The aim of this study was to examine soils developed on clayey parent materials near Strzelin, focusing on their morphology, properties and classification issues. There was confirmed that soils developed from Neogene clays have vertic and mollic horizon, accompanied by stagnic or gleyic properties. However, not all soils fulfil the criteria for Vertisols due to the presence of surface or subsurface coarser-textured (sandyor silty-textured) layers. Native differentiation of parent material and geomorphological processes were found the main factors, which control the spatial mosaic of Vertisols and black earths (Chernozems or Phaeozems).
\end{abstract}

Keywords: Vertisols, Chernozems, Phaeozems, soil classification, mollic, clays

\section{INTRODUCTION}

Bedrock lithology and mineralogy is considered one of the most important factors of pedogenesis as it may determine the soil development and soil basic properties (Waroszewski et al., 2018, 2019). Among various soil types, Vertisols are particularly dependent on parent material and lithology (Table 1). The Neogene and Quaternary clay-rich deposits and regoliths provide a unique primary material for Vertisol formation. Vertisols cover approximately 350 million ha of Earth's surface and the largest areas of Vertisols were identified in Australia, United States, Sudan and India (Ahmad 1996, DeCarlo and Caylor 2019). Vertisols featured by high clay content are difficult to cultivate, although they may have large reserves of nutrients for plants (Miller et al. 2010, $\mathrm{Pal}$ et al. 2012). Genesis of these soils is related to the shrink-swell phenomena of expandable clay minerals that may occur under specific moisture regime, i.e. alternating strong water saturation and deep soil drying (Kabała et al. 2015b, Miller et al. 2010). The most typical environments for Vertisols formation are tropics and subtropics because of extremely dry and extremely wet seasons (Table 1). Vertisol formation is supported by preferential seasonal water accumulation in the local depressions at undulating areas (Syers et al. 2001). It was believed that these soils can be found mostly in tropical/subtropical zones; therefore, for a long time, it was not expected for Vertisols to be formed under the temperate climates of Central Europe (Kovda and Wilding 2004).

Vertisols have been rarely recognized in Poland, thus it is difficult to estimate their distribution across the country. Moreover, clay-rich parent materials occur generally in small patches in Poland, thus drawing the contours of Vertisols in mosaics with other soils may be difficult, in particular on smallscale maps. Vertisols often have dark-coloured and thick topsoil A horizons underlain by subsoil layers with strong redoximorphic features, thus they can be confused with black earths (Labaz and Kabała 2014). The Polish soil classification has not distinguished Vertisols as separate unit for a long time and only suggested their existence as "smolnice" (the term derived from Balkan tradition). Smolnice have been identified in northern Poland, including vicinity of Gniew, Ciechanów, Kętrzyn and Reszel (Mocek et al. 2009, Orzechowski et al. 2014, Owczarzak et al. 1993; Prusinkiewicz 2001; Uggla and Witek 1958). Based on current knowledge and existing soil classification of Poland (Kabała et al. 2019a), the humusrich "smolnice" may be classified as a "wertisole 
TABLE 1. Examples of Vertisols across the world

\begin{tabular}{|c|c|c|c|c|c|c|c|}
\hline \multicolumn{2}{|c|}{ Localization Parent material } & \multirow{2}{*}{$\begin{array}{l}\text { Estimated } \\
\text { land } \\
\text { coverage } \\
\text { (ha) }\end{array}$} & \multirow{2}{*}{$\begin{array}{l}\text { Climate zone } \\
\\
\text { semi-arid moist, humid } \\
\text { tropical, sub-humid moist }\end{array}$} & \multirow{2}{*}{$\begin{array}{l}\text { Mean } \\
\text { annual air } \\
\text { tempera- } \\
\text { ture }\left({ }^{\circ} \mathrm{C}\right) \\
39\end{array}$} & \multirow{2}{*}{$\begin{array}{l}\text { Mean annual } \\
\text { percipitation }\end{array}$} & \multirow{2}{*}{$\begin{array}{l}\begin{array}{l}\text { Original } \\
\text { classificatio }\end{array} \\
\text { Regurs }\end{array}$} & \multirow{2}{*}{$\begin{array}{l}\text { References } \\
\text { Pal et al. } 2001\end{array}$} \\
\hline India & Basalts & & & & & & \\
\hline Sudan & Alluvial sediments & $70 \mathrm{mln}$ & semi-arid/humid & 18 & 1200 & $\begin{array}{l}\text { Black Cotton } \\
\text { soils }\end{array}$ & Ahmad 1996 \\
\hline Australia & $\begin{array}{l}\text { Mesozoic } \\
\text { claystone }\end{array}$ & $70 \mathrm{mln}$ & semi-arid & 21 & $300-800$ & $\begin{array}{l}\text { Black } \\
\text { Earths }\end{array}$ & Ahmad 1996 \\
\hline Texas & $\begin{array}{l}\text { Calcereous } \\
\text { sedimentary } \\
\text { rock }\end{array}$ & $18 \mathrm{mln}$ & humid subtropical & 20 & $760-1150$ & $\begin{array}{l}\text { Grumusols } \\
\text { and } \\
\text { Vertisols }\end{array}$ & Nordt et al. 2004 \\
\hline Mexico & $\begin{array}{l}\text { Basalts and } \\
\text { limestones }\end{array}$ & $0.7 \mathrm{mln}$ & sub-humid & 23.5 & $600-700$ & $\begin{array}{l}\text { Grumusols } \\
\text { and Vertisols }\end{array}$ & $\begin{array}{l}\text { Sotelo-Ruiz et al. } \\
2013\end{array}$ \\
\hline Spain & $\begin{array}{l}\text { Calciferous } \\
\text { sandstones }\end{array}$ & $0.5 \mathrm{mln}$ & mediterranean & 15 & $300-700$ & $\begin{array}{l}\text { Andalusian } \\
\text { black earths }\end{array}$ & $\begin{array}{l}\text { Sánchez-Rodríguez } \\
\text { et al. } 2017\end{array}$ \\
\hline Russia & $\begin{array}{l}\text { Alluvial and marine } \\
\text { sediments }\end{array}$ & - & humid continental & 8 & $400-500$ & Slitozems & $\begin{array}{l}\text { Khitrov and } \\
\text { Rogovneva } 2014\end{array}$ \\
\hline Russia & Lacustrine deposits & - & ultra-continental & -4.2 & 300 & $\begin{array}{l}\text { Vertisolic } \\
\text { soils }\end{array}$ & Kovda et al. 2017 \\
\hline Greece & $\begin{array}{l}\text { River and lacustrine } \\
\text { Pleistocene deposits }\end{array}$ & $0.3 \mathrm{mln}$ & mediterranean & 15.7 & 480 & Haploxerert & Moustakas 2012 \\
\hline Poland & Pleistocene deposits & - & temperate & $7^{\circ} \mathrm{C}$ & 600 & $\begin{array}{l}\text { Black earths } \\
\text { with vertic } \\
\text { properties }\end{array}$ & $\begin{array}{l}\text { Mocek et al. } 2009 \\
\text { Prusinkiewicz } 2001\end{array}$ \\
\hline
\end{tabular}

czarnoziemne" (chernozemic vertisols). The other Vertisols have been evidenced in central-western Poland (Komisarek 2014, unpublished). Vertisols in south western Poland are known from very few sites (Kabała et al. 2015a), although clays present at very shallow depth are relatively common in this region (Kabała et al. 2015b).

Therefore, the aim of this study was to verify diagnostic criteria for Vertisols in SW Poland according to Polish soil classification (Kabała et al. 2019a) and to analyze the sources of soil variability at the transitions between Vertisols and black earths. In particular, the attention was paid to the possibility of field recognition of the diagnostic features of mollic and vertic horizons in clayey soils that has crucial importance for the identification and classification of Vertisols.

\section{MATERIAL AND METHODS}

Five soil pits were located on arable land nearby Dobrogoszcz village (Strzelin county $50^{\circ} 46^{\prime} \mathrm{N}$, $\left.17^{\circ} 01^{\prime} \mathrm{E}\right)$ at the foot of the Niemczańsko-Strzelińskie Hills (Kondracki 2002) (Fig.1), where clayey parent material was previously evidenced at land surface (Góźdź 1957). However, the lithology of surface sediments is highly differentiated. In general, Pleistocene glacial materials, such as glacial till and glaciofluvial sediments, dominate at land surface. The Neogene and Pleistocene glacial sediments quite often are covered (or admixed) with Vistulian loess (Badura et al. 2013, Jary et al. 2002). Although the Quaternary sediments may reach a thickness of $40 \mathrm{~m}$ and more, locally the Neogene clays may occur very near or at land surface (Kural and Jerzmański 1957). The Neogene clays and clayey loams with admixture of glacial till (evidenced by Scandinavian rock fragments and coarse sand fraction) and eolian silt (evidenced by higher content of silt fraction in the surface horizons compared to subsoil layers) occur in the vicinity of Dobrogoszcz village. Locally, also the remnants of a glacio-fluvial (sandy) kames contribute the landscape morphology and compo sition of surface sediments (Kural and Jerzmański 1957).

Mean annual air temperature in area under study is $8^{\circ} \mathrm{C}$, while the mean annual precipitation is 500 $600 \mathrm{~mm}$. The majority of precipitation occurs in warmer half of the year (April-September) and is between 350 and $400 \mathrm{~mm}$. In colder months (October-March) of the year the precipitation is clearly lower, between 150 and $200 \mathrm{~mm}$. The annual clima- 
FIGURE 1. Location of the study area and soil profiles

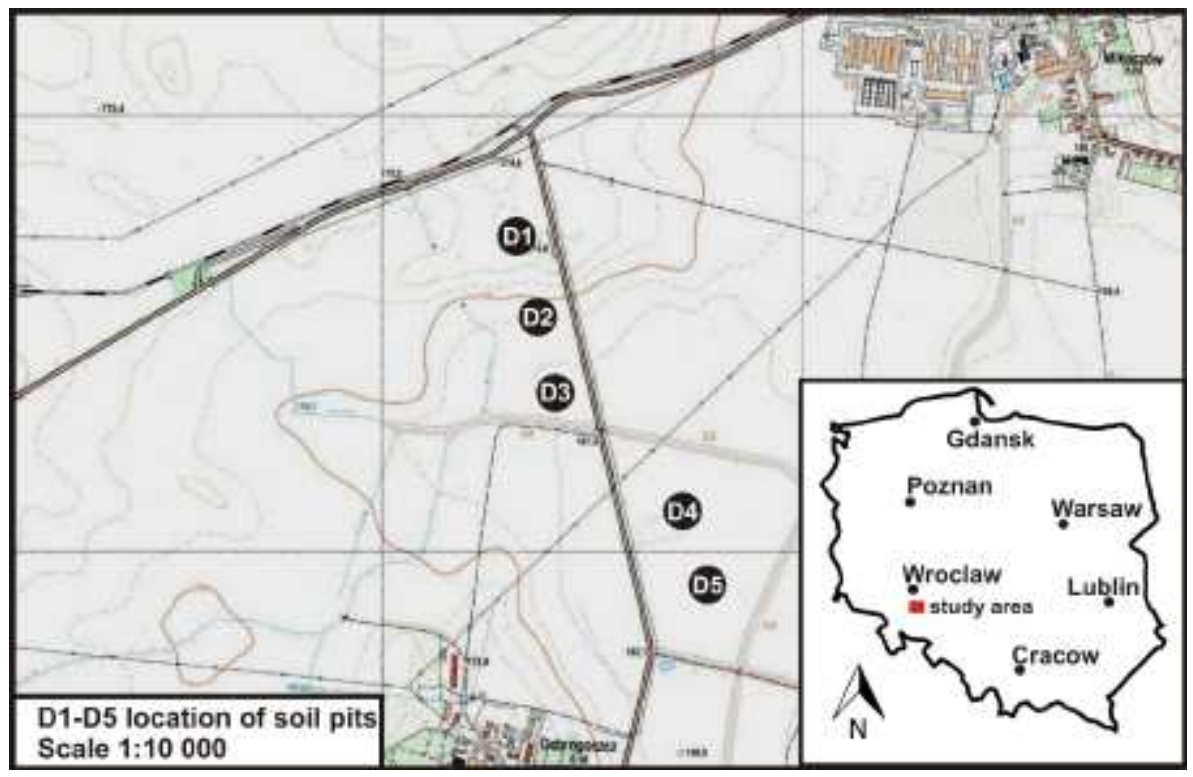

tic water balance (precipitation minus evapotranspiration) is slightly positive $(+40 \mathrm{~mm})$, mainly due to positive water balance in winter months. Whereas, the climatic water balance in summer months is negative, that means the water shortage and soil droughts are seasonally highly probable in this region, even under temperate climate (Pawlak and Pawlak 2008).

The sequence of five soil profiles was localized on a gently smooth SW slope. The arable fields (corn, wheat, raps) are drained with an open-ditch network (Fig. 1). All soil profiles were described and classified according to Polish soil classification (Kabała et al. 2019a) and the FAO-WRB system (IUSS Working Group WRB 2015). Soil samples, collected for laboratory analyzes from all horizons, were air-dried, manually crushed and sieved using a $2 \mathrm{~mm}$ mesh. Particle-size distribution was conducted using sieves for sand fractions and the hydrometer method for clay and silt fractions after sample dispersion with hexametaphosphate-bicarbonate, according to the legal standard PN-R-04032. Texture classes were named after Polish (Polskie Towarzystwo Gleboznawcze 2009) (Table 3) and WRB classifications (IUSS Working Group WRB 2015). Soil organic carbon content was determined by dry combustion method (using the CS-MAT analyzer). Soil pH was measured in distilled water and in $1 \mathrm{M} \mathrm{KCl}$ solution (at a 1:5 ratio). Content of calcium carbonates (equivalent) was determined volumetrically (Scheibler apparatus). Content of exchangeable base cations was determined by ICP-ES method after extraction with ammonium acetate (at $\mathrm{pH} 7$ ) and exchangeable acidity was determined potentiometrically after extraction with $1 \mathrm{M} \mathrm{KCl}$ (Kabała and Karczewska 2018). Base satu- ration was calculated as a percentage of base cations sum in an effective cation exchange capacity (base cations plus exchangeable acidity).

Hard nodules of secondary carbonates were sampled in profile D1 for their age estimation using $14^{\circ} \mathrm{C}$ AMS (accelerator mass spectrometry) dating technique in Poznań Radiocarbon Laboratory. Calendar age for sample Poz-98379 was obtained using the OxCal 4.2 calibration program (Bronk Ramsey 2009) based on the IntCal 13 calibration curve (Reimer et al. 2013). Calibrated ages are given in the $2 \sigma$ range, minimum and maximum values.

\section{RESULTS}

All profiles in the catena have similar morphology, manifested in the following general sequence of soil horizons: Ap-ABig-Big. The thickness of A horizons varied in a range from $31 \mathrm{~cm}$ (profile D4) to $70 \mathrm{~cm}$ (profile D2). The lower limit of A horizons has different morphology. In some profiles, the transition to $\mathrm{Bi}$ horizon is smooth with narrow dark tongues; while in other profiles the transition is irregular with thick tongues. In the most specific case of the profile D2, fragments of underlying material are incorporated into black matrix of A horizon (Fig. 2). Plough horizons generally have strong subangular and angular blocky structure, in some profiles also the granular one, variable in size (fine to coarse), and hard consistence in a dry state. The clods formed by ploughing are coarse in size, but smaller than $30 \mathrm{~cm}$ in diameter and always have internal blocky subangular structure, even if hard. Topsoil A horizons are black or nearly black (10YR 2/1-3/1; Table 2), contain 1.6-2.5\% of organic carbon and are featured with slightly 


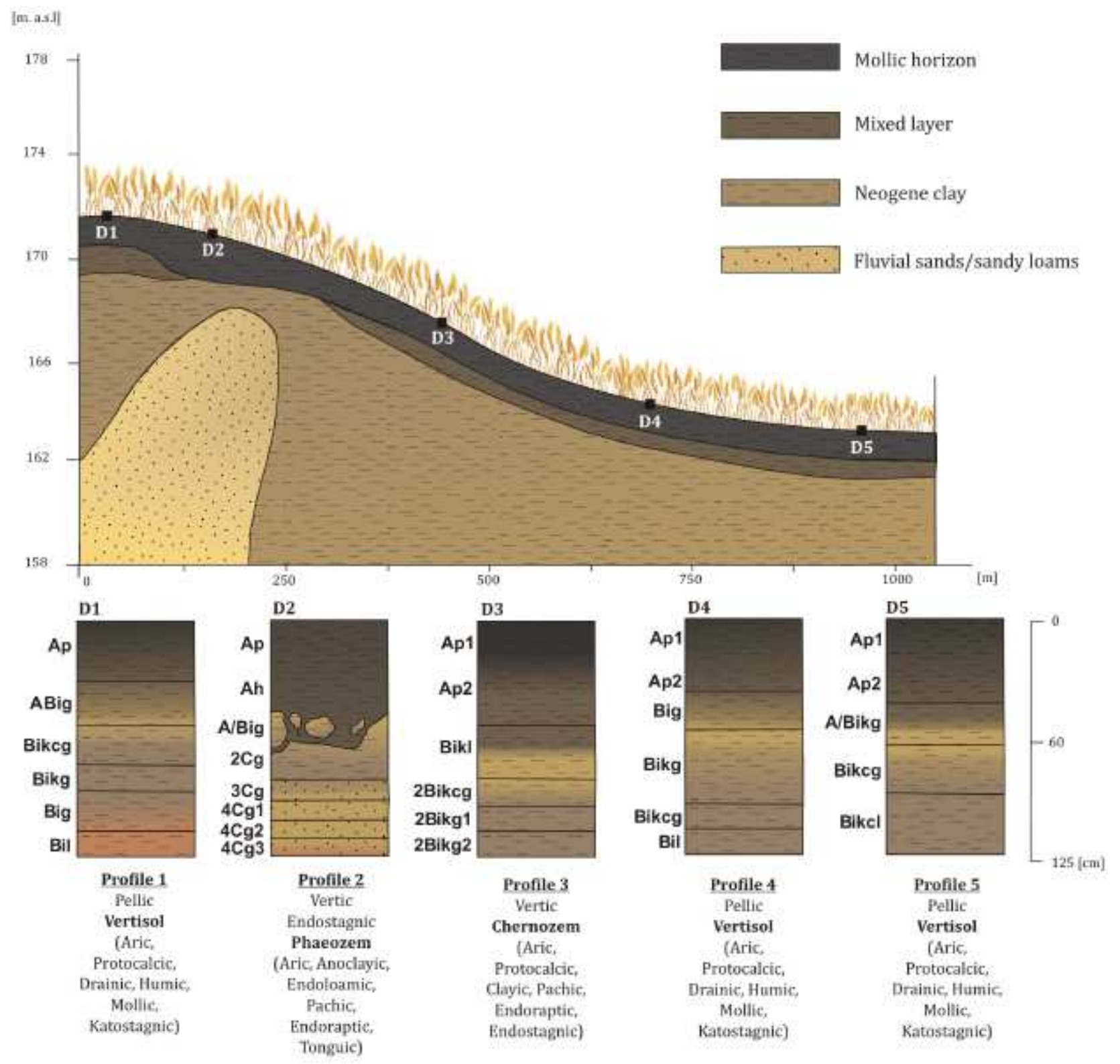

FIGURE 2. Toposequence of soil profiles

alkaline reaction and very high base saturation (Table 4). Taking into account both morphological and physico-chemical properties, the topsoil layers meet the criteria of diagnostic mollic horizon in all soil profiles of the catena. The A horizons contain in most cases more than $30 \%$ of clay fraction and have texture of silty clay loam, silty clay and clay loam classes (Table 3). Only the A horizon in the profile D2 has $19 \%$ of clay and texture class of loam. All A horizons have higher content of silt fraction than the subsoil layers, and the profiles located in the lower slope positions (D3, D4 and D5) contain clearly more silt that the profiles D1 and D2. Open cracks were absent in A horizons during the pit digging and description; however, the narrow black tongues that probably are closed cracks filled with humus-rich material from A horizon are recognizable in transitional $\mathrm{AB}$ and $\mathrm{Bi}$ horizons of all profiles, in particular in the profile D5.

The subsurface vertic horizons were identified in all profiles, according to both FAO-WRB system (IUSS Working Group WRB 2015) and Polish soil Classification (Kabała et al. 2019a). These horizons have all required diagnostic features of vertic horizon, i.e. contain $\geq 30 \%$ of clay fraction (Table 3 ), have a thickness of $\geq 25 \mathrm{~cm}$ (Table 2), the vertical cracks (filled and seasonally closed; Fig. 3c), the wedge-shaped or lenticular structural aggregates and the slickensides on the surfaces of structural aggregates (Fig. 3a, 3d). The presence of wedge-shaped 
TABLE 2. Field soil characteristics

\begin{tabular}{|c|c|c|c|c|c|c|c|c|c|}
\hline \multirow{2}{*}{$\frac{\text { Profile }}{\text { ID }}$} & \multirow[t]{2}{*}{ Horizon } & \multirow{2}{*}{$\frac{\text { Depth }}{(\mathrm{cm})}$} & \multicolumn{3}{|c|}{ Colour (moist) } & \multirow[t]{2}{*}{ Structure } & \multicolumn{2}{|c|}{ Consistence } & \multirow[t]{2}{*}{ Carbonates } \\
\hline & & & Matrix & Oximorphic & Reductomorphic & & moist & dry & \\
\hline \multirow[t]{6}{*}{ D1 } & Ap & $0-38$ & $10 \mathrm{YR} 3 / 2$ & - & - & SA/GR & FR & HA & - \\
\hline & $\overline{\mathrm{ABig}}$ & $38-70$ & $\begin{array}{l}10 \text { YR } 3 / 1 \\
10 \text { YR } 5 / 6\end{array}$ & - & - & $\mathrm{AB}$ & FR/FI & HA & - \\
\hline & Bikcg & $70-105$ & 10YR 5/6 & - & $5 Y 6 / 3$ & $\mathrm{AB}+\mathrm{WE}$ & FI/VFI & HA & $\mathrm{n}$ \\
\hline & Bikg & $105-125$ & - & $5 \mathrm{Y} 6 / 2$ & $2.5 Y 5 / 4$ & $\mathrm{AB}+\mathrm{WE}$ & EFI & VHA & + \\
\hline & $\mathrm{Big}$ & $125-160$ & - & 10YR 6/6 & $5 Y 6 / 2$ & $\mathrm{AB}+\mathrm{WE}$ & EFI & VHA & - \\
\hline & $\overline{\text { Bil }}$ & $160-180$ & - & $2.5 Y 5 / 6$ & $2.5 \mathrm{Y} 7 / 1$ & WE & EFI & VHA & - \\
\hline \multirow[t]{8}{*}{ D2 } & $\mathrm{Ap}$ & $0-35$ & 10YR 2/1 & - & - & SB/GR & FR & HA & - \\
\hline & $\overline{\mathrm{Ah}}$ & $35-68$ & 10YR 2/1 & - & - & SA & FR/FI & HA & - \\
\hline & $\mathrm{A} / \mathrm{Big}$ & $68-95$ & 10YR 2/1 & - & $2.5 \mathrm{Y} 6 / 3$ & $\mathrm{SB}+\mathrm{WE}$ & VFI & HA & - \\
\hline & $2 \mathrm{Cg}$ & $95-122$ & - & 7.5 YR $5 / 8$ & $2.5 \mathrm{Y} 6 / 3$ & $\mathrm{AB}$ & FI & HA & - \\
\hline & $3 \mathrm{Cg}$ & $122-130$ & - & 7.5 YR $5 / 8$ & $2.5 \mathrm{Y} 6 / 3$ & $\mathrm{AB}$ & FI/VFI & HA & - \\
\hline & $4 \mathrm{Cg} 1$ & $130-140$ & - & 7.5YR 5/8 & 2.5 Y $5 / 3$ & $\mathrm{AB}$ & FI & $\mathrm{SO}$ & - \\
\hline & $4 \mathrm{Cg} 2$ & $140-150$ & - & 10 YR $5 / 8$ & - & SB & FI & $\mathrm{SO}$ & - \\
\hline & $4 \mathrm{Cg} 3$ & $150-178$ & - & 2.5 YR $3 / 6$ & - & SB & FI & $\mathrm{SO}$ & - \\
\hline \multirow[t]{6}{*}{ D3 } & Ap1 & $0-18$ & 10YR 2/1 & - & - & SA/GR & FR & HA & - \\
\hline & Ap2 & $18-40$ & 10YR 2/1 & - & - & $\mathrm{AB}$ & $\mathrm{FR} / \mathrm{FI}$ & HA & - \\
\hline & Bikl & $40-68$ & - & $\begin{array}{l}10 \mathrm{YR} 5 / 6 \\
2.5 \mathrm{YR} 3 / 6\end{array}$ & $\begin{array}{l}2.5 \mathrm{YR} \\
5 / 3\end{array}$ & $\mathrm{WE}+\mathrm{AB}$ & VFI & VHA & + \\
\hline & 2Bikcg & $68-88$ & - & $\begin{array}{l}10 \text { YR 5/8 } \\
7.5 \text { YR 5/8 }\end{array}$ & $2.5 Y 5 / 4$ & $\mathrm{WE}+\mathrm{AB}$ & VFI/EFI & VHA & $\mathrm{n}$ \\
\hline & 2Bikg1 & $88-110$ & - & 10YR 5/6 & $5 Y 6 / 4$ & $\mathrm{WE}+\mathrm{AB}$ & EFI & VHA & + \\
\hline & 2Bikg2 & $110-135$ & - & 10YR 5/6 & $5 \mathrm{Y} 6 / 4$ & $\mathrm{WE}+\mathrm{AB}$ & EFI & VHA & + \\
\hline \multirow[t]{6}{*}{ D4 } & Ap1 & $0-14$ & 10YR 2/1 & - & - & SB & FR & HA & - \\
\hline & Ap2 & $14-31$ & 10YR 2/1 & - & - & $\mathrm{AB}$ & FR/FI & HA & - \\
\hline & Big & $31-54$ & - & 10YR 5/8 & $5 Y 5 / 2$ & $\mathrm{WE}+\mathrm{AB}$ & VFI & VHA & - \\
\hline & Bikg & $54-105$ & - & 10YR 5/8 & $5 Y 5 / 2$ & $\mathrm{WE}+\mathrm{AB}$ & VFI/EFI & VHA & + \\
\hline & Bikcg & $105-130$ & - & 10YR 5/6 & $5 Y 5 / 2$ & WE & EFI & VHA & $\mathrm{n}$ \\
\hline & Bil & $>130$ & - & 10YR 5/6 & $5 Y$ 6/2 & WE & EFI & VHA & - \\
\hline \multirow[t]{5}{*}{ D5 } & Ap1 & $0-15$ & 10YR 2/1 & - & - & $\mathrm{SA}$ & FR & HA & - \\
\hline & Ap2 & $15-40$ & 10YR 2/1 & - & - & $\mathrm{AB}$ & FR/FI & HA & - \\
\hline & $\mathrm{A} / \mathrm{Bikg}$ & $40-70$ & - & 10YR 5/8 & 2.5 YR $5 / 1$ & $\mathrm{WE}+\mathrm{AB}$ & VFI/EFI & VHA & + \\
\hline & Bikcg & $70-100$ & - & 10YR 5/6 & $5 Y 5 / 1$ & $\mathrm{WE}+\mathrm{AB}$ & EFI & VHA & $\mathrm{n}$ \\
\hline & Bikcl & $100-135$ & - & 10YR 5/6 & $5 Y 5 / 1$ & $\mathrm{WE}+\mathrm{AB}$ & EFI & VHA & $\mathrm{n}$ \\
\hline
\end{tabular}

Explanations: structure: GR - granular, AB - blocky angular, SA - blocky subangular and angular, SB - blocky subangular, WE - wedge-shaped; carbonates: + - few, $\mathrm{n}$ - hard nodules; consistence (moist): FR - friable, FI - firm, VFI - very firm, EFI - extremely firm; consistence (dry): SO - soft, HA - hard, VHA - very hard.

aggregates with slickensides is visible not only in $\mathrm{Bi}$, but also in overlying transitional horizons and even in lower parts of clayey A horizons.

The content of carbonates in the profiles D1, D3, D4 and D5 ranges from 0.1 to $9.8 \%$ and increases in the profiles from the surface down to the depth of $88-130 \mathrm{~cm}$, where it reaches the maximum and then decreases (Table 4). Surface horizons have signs of decalcification, whereas the underlying transitional horizons have visible accumulation of secondary (pedogenic) carbonates, mostly in the form of hard nodules, fine to moderate in size. Profile D2 is an exception, as it is poor in carbonates (up to $0.1 \%$ ) or completely free of them in some layers; moreover, the highest content of carbonates (probably of anthropogenic origin) is noted in the topsoil (Table 4).

A predominance of stagnic properties is clearly manifested in all subsurface horizons, though it varies in intensity and contribution of reductomorphic and oximorphic colours. Reductomorphic colours are represented with grey (2.5Y 5/2-4) or more olive (5Y 5-6/1-4) colours. Reducing conditions are particularly 

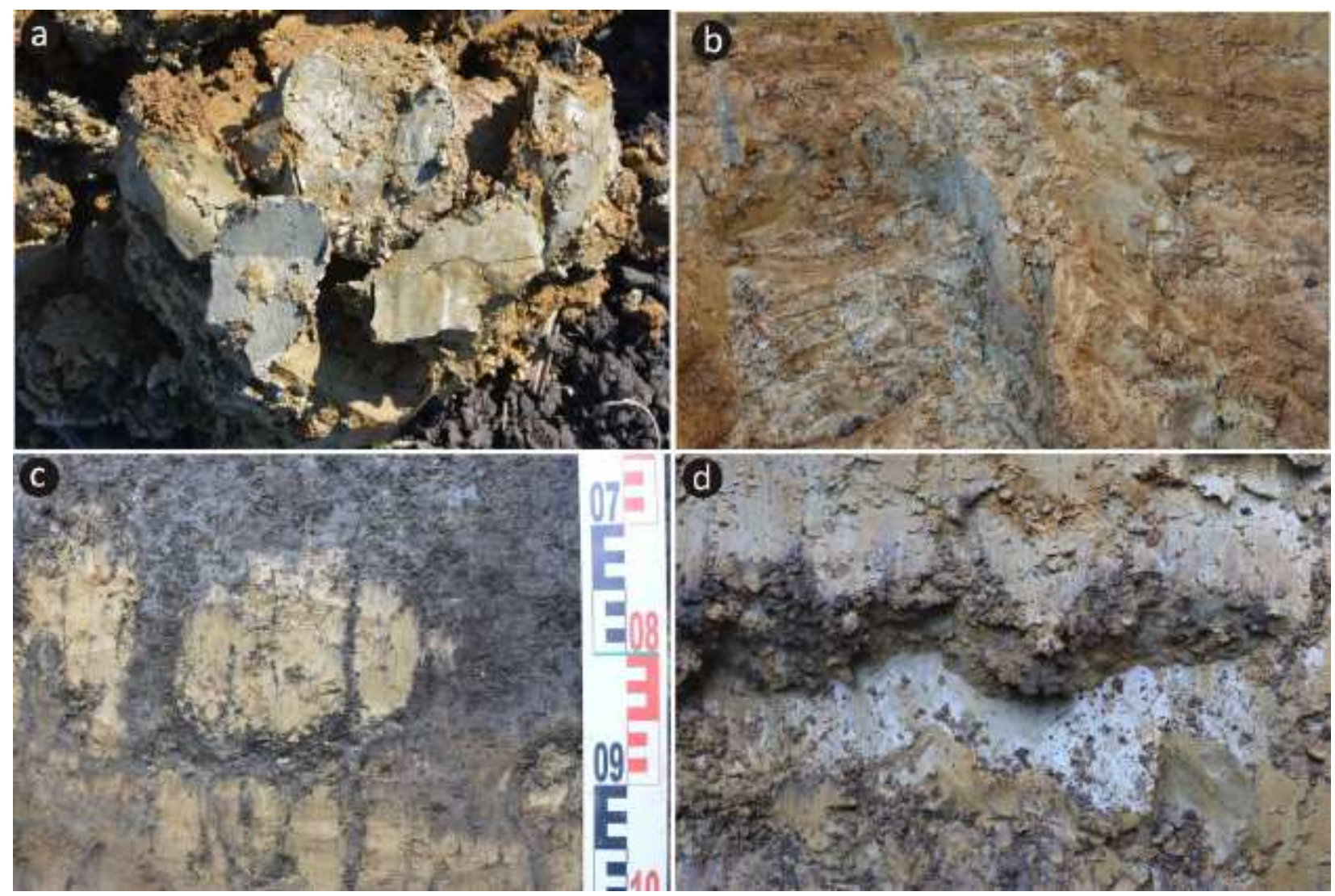

FIGURE 3. Effects of shrinking-swelling phenomena in soils under study: (a) shining surfaces on soil peds, (b) closed narrow cracks in the lowermost horizon in profile D5 with reductomorphic colours developing along the cracks, (c) fragments of subsoil material "incorporated" into A horizon in the profile D2; closed narrow cracks filled with dark (humus-rich) material, (d) slickensides on the surfaces of lenticular aggregates (cross section in the wall of the profile D1)

visible along cracks, which most likely are seasonally filled with stagnating (surface) water in a deep subsoil horizons in the profile D5 (Fig. 3b), as well as on the surfaces of wedge-shaped/lenticular aggregates (Fig. 3d). Among the oximorphic colours prevail such as 10YR 5/6-8 or more reddish 7.5YR 5/8. Deep subsoil horizons (below the depth of $130 \mathrm{~cm}$ ) of the profiles D1, D4 and D5 are featured with the gleyic properties (Table 2), resulting from permanent soil saturation with infiltrating water. In profiles D2 and D3, the gleyic properties were noticed also at a depth of $68-95 \mathrm{~cm}$ and $40-68 \mathrm{~cm}$, respectively. In both cases the gleyic properties have developed within or directly above horizons having clearly higher clay content that neighboring horizons. The reductomorphic colours of strongly saturated horizons are mostly grey (5Y5-6/1-2 or $2.5 \mathrm{Y} 7 / 1)$ and cover up to $75-85 \%$ of the cross-section, including the internal parts of soil aggregates.

\section{DISCUSSION}

\section{Diagnostic features and classification of soils in a catena}

All soils in a catena have a subsurface vertic horizons featured by: clayey texture $(30 \%$ of clay fraction or more), presence of wedge-shaped (or lenticular) structural aggregates inclined at various angle, slickensides on the surfaces of these aggregates, and cracks filled with humus-rich material falling from A horizon during dry seasons (when cracks presumably are open). All this confirms the shrinkswell phenomena to be active. With an exception of the profile $\mathrm{D} 2$, these vertic horizons have a thickness much larger than required $25 \mathrm{~cm}$. Vertic horizons do not have specific colour and may be both similar to underlying parent material, may be covered with a redoximorphic colour pattern, as well as may belong to A horizon (its lower part). The recognition of Vertisol requires both the presence of vertic horizon and, additionally, a clayey texture (i.e. ?30\% of clay fraction) in all layers between soil surface and vertic horizon (IUSS Working Group WRB 2015, Kabała 
et al. 2019a). Only the profiles D1, D4 and D5 fulfill these two requirements; whereas the Ap horizon in profile $\mathrm{D} 2$ and Bikl horizon in profile $\mathrm{D} 3$ have loamy texture classes with less than $30 \%$ of clay fraction (Table 3).

The other important issue under consideration was the recognition of mollic horizons in clay-textured soils. All topsoil A horizons contain $>1.6 \%$ of organic carbon, have black or nearly black colour, slightly alkaline reaction and base saturation much higher than $50 \%$ (Table 4), thus meet basic morphological and physico-chemical criteria for diagnostic mollic horizon. However, the possibility of mollic horizon presence in clay-textured soils in Poland was questioned (Polish Soil Classification 2011) due to its hard consistence and massive structure in a dry state. In fact, the soil consistence in the plough horizons is hard in a dry state; however, the structure is in all horizons blocky subangular and angular, in some parts even granular. The clods produced by ploughing (angular blocks) are smaller than $30 \mathrm{~cm}$ in diameter and always have internal blocky structure. Thus, even if the consistence of aggregates is hard in dry state, the aggregate structure of topsoil horizons cannot be recognized as massive following the diagnostic requirements for mollic horizon (IUSS Working Group WRB 2015, Kabała et al. 2019a). Taking into account both morphological and physico-chemical properties, including the non-massive structure, the topsoil horizons meet the criteria of diagnostic mollic horizon in all soil profiles under study.

Soils in the profiles D2 and D3 have a thick mollic horizon and slightly alkaline or alkaline reaction, connected with high base saturation throughout the profile that allows their classification, respectively, as Phaeozem (no calcic/protocalcic properties) or Chernozem, if the calcic/protocalcic properties are present in subsurface layers (IUSS Working Group WRB 2015). It must be stated that the present definition of chernic horizon (IUSS Working Group WRB 2015) requires a granular or fine subangular blocky structure that would not be the case of Ap horizon in the profile D3 (as in many other ploughed layers of chernozemic soils), shifting this soil to Kastanozems. However, this error has already been identified by WRB Working Group and the change of the size criteria for structural aggregates in chernic horizon has been agreed $(+$, personal communication). Also according to Classification of Polish Soils (Kabała et al. 2019a), the profiles D2 and D3 cannot be named vertisols, but "vertisolic black earths" distinguished as soils that have mollic horizon, strong redoximorphic features and vertic horizon, but do not have clayey texture in all horizons from the surface down to the vertic horizon (final soil names are given in Table 3).
All soils under study (including the Vertisol profiles D1, D4 and D5) are seasonally excessively saturated with surface water (from snow melting and precipitation) and are drained (using the open ditches). Due to seasonal saturation with water and reducing conditions, all soils have well developed stagnic properties starting directly below the A horizon and covering vertic horizons/subhorizons. The loamy Bikl horizon in the profile D3 (at a depth of 40-68 cm), underlain by much finer clay loam, is probably much longer saturated with water (compared to other soil layers), thus the reductomorphic colours dominate in this horizon and gleyic properties may be recognized instead of stagnic properties. Although the calcic horizons are absent, the accumulation of secondary carbonates in subsurface horizons allows to recognize the protocalcic properties in profiles D1, D4 and D5 (and also D3, as stated above).

Finally, the Vertisols in profiles D1, D4 and D5 have in their full names, derived after the WRB rules (IUSS Working Group WRB 2015), only one primary qualifier-Pellic. The Pellic qualifier refers to the presence of thick and dark topsoil A horizon (that may or may not meet the criteria for mollic horizon). An expected Grumic qualifier (that refers to the presence of a self-mulching fine-structural topsoil layer) is disputable, as this layer may be easily destroyed by ploughing, thus may occur in these soils only seasonally. During the profile description, the self-mulching layers have not been recognized. Moreover, the following supplementary qualifiers may be added: Aric (soils are ploughed to the depth of $20 \mathrm{~cm}$ and more), Protocalcic, Drainic, Humic, Mollic and Katostagnic, as explained above (Table 3).

According to Polish Soil Classification (Kabała et al. 2019a), profiles D1, D4 and D5 are "chernozemic vertisols", where vertic and mollic horizons (thicker than $30 \mathrm{~cm}$ ) are required and stagnic properties typically are presumed (Table 3 ).

\section{Origin of soil variability in the landscape}

A recognition of Vertisols as a separate soil unit is highly dependent on the clayey soil texture and any coarse-textured admixture or layering may result in a change of soil classification, as these additions may weaken or prevent the shrinking-swelling phenomena (DeCarlo and Caylor 2019; Miller et al. 2010). Meanwhile, the spatial and vertical variability of sediments, and therefore also soil texture, is common in the post-glacial landscapes of Poland, including the Lower Silesia region (Kabała et al. 2015b). This is a result of repeated Pleistocene glaciations, erosion of glacial materials, Late Pleistocene (peri- 


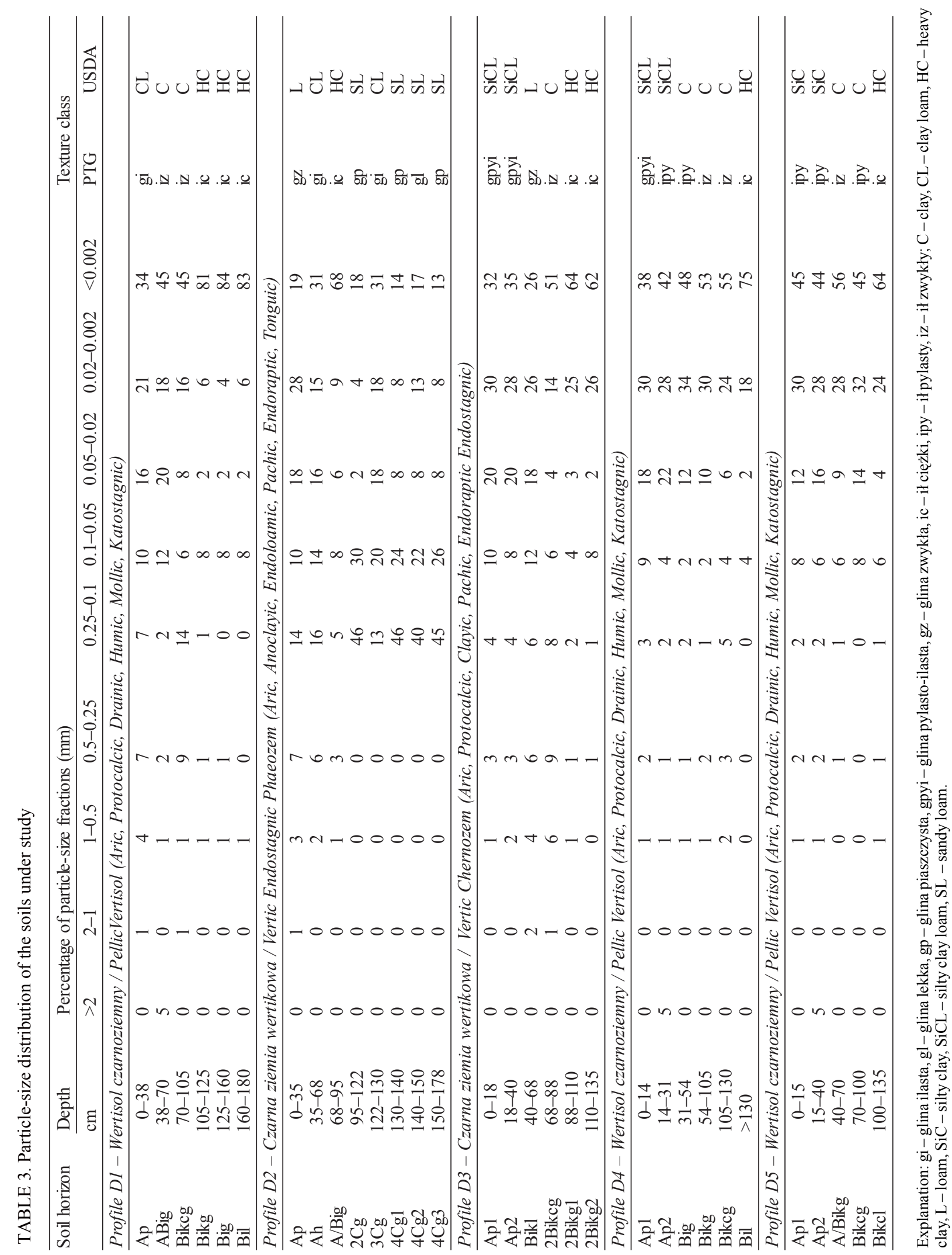


TABLE 4. The physicochemical properties of soils under study

\begin{tabular}{|c|c|c|c|c|c|c|c|c|c|c|}
\hline \multirow[t]{2}{*}{ Profile ID } & \multirow[t]{2}{*}{ Horizon } & \multirow[t]{2}{*}{$\begin{array}{l}\text { Depth } \\
(\mathrm{cm})\end{array}$} & \multirow[t]{2}{*}{$\begin{array}{l}\mathrm{pH} \\
\mathrm{H}_{2} \mathrm{O}\end{array}$} & \multirow[t]{2}{*}{$\begin{array}{l}\mathrm{pH} \\
\mathrm{KCl}\end{array}$} & $\mathrm{CaCO}_{3}$ & $\mathrm{C}$ & $\mathrm{N}$ & $\begin{array}{l}\text { Exchange-- } \\
\text { able acidity }\end{array}$ & $\begin{array}{l}\text { Sum of } \\
\text { base } \\
\text { cations }\end{array}$ & \multirow[t]{2}{*}{$\begin{array}{l}\text { Base } \\
\text { saturation }\end{array}$} \\
\hline & & & & & \multicolumn{3}{|l|}{$\%$} & \multicolumn{2}{|c|}{$\left(\operatorname{cmol}(+) \cdot \mathrm{kg}^{-1}\right)$} & \\
\hline \multirow[t]{6}{*}{ D1 } & Ap & $0-38$ & 7.50 & 6.67 & 0.21 & 1.64 & 0.12 & 2.66 & 22.5 & 89 \\
\hline & ABig & $38-70$ & 7.76 & 6.47 & 0.14 & 0.60 & 0.05 & 1.90 & 24.2 & 93 \\
\hline & Bikcg & $70-105$ & 8.46 & 7.36 & 6.80 & 0.18 & n. d. & 0.95 & 48.7 & 98 \\
\hline & Bikg & $105-125$ & 8.12 & 7.05 & 2.27 & 0.12 & n. d. & 1.20 & 55.3 & 98 \\
\hline & Big & $125-160$ & 8.03 & 7.12 & 1.44 & 0.07 & n. d. & 1.30 & 46.0 & 97 \\
\hline & Bil & $160-180$ & 8.10 & 7.00 & 0.34 & 0.08 & n. d. & 1.30 & 42.9 & 97 \\
\hline \multirow[t]{8}{*}{ D2 } & Ap & $0-35$ & 7.20 & 6.51 & 0.11 & 2.36 & 0.17 & 3.24 & 21.4 & 87 \\
\hline & $\mathrm{Ah}$ & $35-68$ & 7.23 & 6.35 & 0.04 & 1.45 & 0.11 & 3.14 & 21.0 & 87 \\
\hline & $\mathrm{A} / \mathrm{Big}$ & $68-95$ & 7.73 & 6.31 & 0.06 & 0.53 & 0.04 & 2.50 & 33.0 & 93 \\
\hline & $2 \mathrm{Cg}$ & $95-122$ & 8.00 & 6.58 & 0.04 & 0.14 & n. d. & 1.02 & 1.20 & 54 \\
\hline & $3 \mathrm{Cg}$ & $122-130$ & 8.20 & 6.75 & 0.02 & 0.22 & n. d. & 1.43 & 2.12 & 60 \\
\hline & $4 \mathrm{Cg} 1$ & $130-140$ & 8.29 & 7.00 & 0.02 & 0.09 & n. d. & 0.85 & 1.17 & 58 \\
\hline & $4 \mathrm{Cg} 2$ & $140-150$ & 8.35 & 7.10 & 0.00 & 0.12 & n. d. & 0.68 & 1.41 & 67 \\
\hline & $4 \mathrm{Cg} 3$ & $150-178$ & 8.28 & 7.06 & 0.00 & 0.03 & n. d. & 0.68 & 11.3 & 94 \\
\hline \multirow[t]{6}{*}{ D3 } & Ap1 & $0-18$ & 7.42 & 6.71 & 0.06 & 2.03 & 0.16 & 2.07 & 25.2 & 92 \\
\hline & Ap2 & $18-40$ & 7.69 & 7.03 & 0.17 & 2.00 & 0.14 & 1.80 & 23.2 & 93 \\
\hline & Bikl & $40-68$ & 8.34 & 7.57 & 4.37 & 0.23 & 0.02 & 0.79 & 26.6 & 97 \\
\hline & 2Bikcg & $68-88$ & 8.21 & 7.40 & 9.75 & 0.23 & n. d. & 0.95 & 39.1 & 98 \\
\hline & 2Bikg1 & $88-110$ & 8.14 & 7.31 & 4.45 & 0.18 & n. d. & 1.20 & 39.3 & 97 \\
\hline & 2Bikg2 & $110-135$ & 8.09 & 7.19 & 1.87 & 0.11 & n. d. & 1.10 & 38.1 & 97 \\
\hline \multirow[t]{6}{*}{ D4 } & Ap1 & $0-14$ & 7.26 & 6.15 & 0.06 & 2.05 & 0.16 & 2.34 & 25.2 & 92 \\
\hline & Ap2 & $14-31$ & 7.46 & 6.33 & 0.04 & 1.99 & 0.14 & 2.47 & 27.7 & 92 \\
\hline & Big & $31-54$ & 8.24 & 6.89 & 0.35 & 0.28 & 0.02 & 1.14 & 28.9 & 96 \\
\hline & Bikg & 54-105 & 8.33 & 7.09 & 3.89 & 0.16 & n. d. & 0.95 & 42.7 & 98 \\
\hline & Bikcg & $105-130$ & 8.24 & 7.26 & 9.82 & 0.21 & n. d. & 1.14 & 44.3 & 97 \\
\hline & Bil & $>130$ & 8.29 & 7.04 & 0.79 & 0.06 & n. d. & 1.00 & 41.0 & 98 \\
\hline \multirow[t]{5}{*}{ D5 } & Ap1 & $0-15$ & 7.99 & 7.16 & 1.08 & 2.47 & 0.18 & 1.62 & 40.6 & 96 \\
\hline & Ap2 & $15-40$ & 8.16 & 7.16 & 1.41 & 2.17 & 0.16 & 1.33 & 40.4 & 97 \\
\hline & $\mathrm{A} / \mathrm{Bikg}$ & $40-70$ & 8.37 & 7.16 & 1.70 & 0.56 & 0.05 & 1.14 & 55.3 & 98 \\
\hline & Bikcg & $70--100$ & 8.44 & 7.32 & 8.68 & 0.10 & n. d. & 0.95 & 37.8 & 98 \\
\hline & Bikcl & $100-135$ & 8.26 & 7.28 & 6.20 & 0.11 & n. d. & 1.10 & 42.1 & 97 \\
\hline
\end{tabular}

Explanation: n. d. - not determined.

TABLE 5. Radiocarbon date of carbonates nodule from profile D1

\begin{tabular}{llll}
\hline $\begin{array}{l}\text { Laboratory } \\
\text { code }\end{array}$ & $\begin{array}{l}\text { Sampling } \\
\text { depth }(\mathrm{cm})\end{array}$ & ${ }^{14} \mathrm{C}$ age (measured) & ${ }^{14} \mathrm{C}$ calibrated age \\
\hline Poz -98379 & $70-80$ & $3915+/-35 \mathrm{BP}$ & $2487 \mathrm{BC}(95.4 \%) 2291 \mathrm{BC}=4241-4437 \mathrm{cal} \mathrm{BP}$ \\
\hline
\end{tabular}

Explanation; BC - before Christ, BP - before present (1950). 
glacial) eolian accumulation, and slope processes that may both mix and translocate the sediments (Waroszewski et al. 2019). All these transformations are believed to occur subsequently in the catena under study. The main parent material for the local soils is Neogene clay that contains here $45-84 \%$ of clay fraction and does not contain coarse gravel/stone fractions (Table 3). Typical glacial tills are absent in the catena under study, despite of at least two Scandinavian glaciations, which covered this area. The subrounded rock fragments (medium and coarse gravels) are only relics of these tills admixed to underlying clays (recognizable in particular in the profiles D4 and D5). High content of silt fraction in the topsoil horizons, up to $48-50 \%$ in the profiles D4 and D5, indicates eolian addition, which was very common in the Lower Silesia during the Pleniglacial period of the Last Glacial Maximum (Waroszewski et al. 2018). It is unknown, whether (1) the pure loess layer initially covered the soils in the catena and then it was eroded, or (2) eolian silt was mixed by slope processes under periglacial conditions directly after its sedimentation and did not form separate silt layer. Nevertheless, both these scenarios may result in a formation of similar silt-enriched mixed topsoil layer (Waroszewski et al. 2018).

Moreover, eroded remnants of the kame-type landform (consisting of glacio-fluvial sediments) have been recognized east of the catena (Kural and Jerzmański 1957). Sands from the eroded kame could reach the upper part of the catena that is recognizable as clearly higher content of sand fraction in topsoil horizons of profile D2 and, to a lesser extent, of profile D3 (Table 3). The presence of medium and coarse sand in the profile D3 confirms the importance of slope processes that transported the soil material downward along the slope. The most disputable is the origin of "clayey sand" (sandy loam in terms of pedological texture classifications) present in the subsoil layers of the profile D2. The most probable is that sand-rich material is a lens of fluvial/lacustrine sediments interbedding the Neogene clays. However, it is only a hypothesis as no deep excavation or drilling was made to check it.

Undoubtedly, the current morphology of the profiles and soil properties are a result of different phases of pedogenesis. It is believed that thick chernozemic horizons started to form in southwestern Poland as early as in Late Pleistocene (Kabala et al. 2019a). It is also probable that the A horizons have been "rejuvenated" and deepened since the Neolithic period, i.e. after large-scale forest clearing and spreading of the forest-steppe vegetation ( abaz et al. 2019). The formation of vertic horizon was possible in the Holocene period, where the summer and winter seasons became alternately enough dry and moist to allow the development of wedge-shaped aggregates and slickensides in the clayey subsoil (Pal et al. 2012, Pierre et al. 2018). Kabala et al. (2015b) argue that the artificial drainage after clearing the forest could promote the shrinkswell phenomena by enhancing the topsoil drying in summer, even under generally moist temperate climate. Therefore, the post-Neolithic Subboreal-Subatlantic periods are considered favorable periods for the formation of vertic horizons and Vertisol development in arable lands of Central Europe (on a clayey substrates). This hypothesis is convergent with an age of carbonate nodules from the profile D1 (Table 5). Radiocarbon date approximates the first part of Subboreal period as a time of intense decalcification of initially carbonate-rich soil substrate due to strong leaching driven by moist climate. The same environmental factor (long term moistening of the climate) that led to carbonate leaching and supported the shrink-swell phenomena (and formation of vertic horizons), also resulted in a development of redoximorphic features (mostly the stagnic properties), which strong expression is important diagnostic feature. Possibility of "gilgai" microrelief formation in SW Poland was confirmed by Kabala et al. (2015b), also on gentle slopes. However, the presence of "gilgai" in the catena under study has not been identified as it is typically destroyed by regular and deep ploughing (modern agriculture activities) that led to surface flattening.

\section{CONCLUSIONS}

The analyses of morphological features of soils located near Strzelin allow confirming the presence of Vertisols in this area. Clay-rich parent material, in combination with seasonally alternating water saturation promotes the formation of vertic properties (slickensides and deep cracks) also under temperate climate of SW Poland. Moreover, seasonal soil saturation with water allows stabilization and accumulation of the organic matter in topsoil layer. Under these conditions, humus-rich Vertisols featured by thick mollic horizon form a spatial mosaic with other humus-rich soils - Phaeozems and Chernozems. High spatial variability of Vertisols and accompanying soils is an effect of textural soil variability, resulting both from native variability of parent materials and geomorphological processes. Similar to black earths Pellic Vertisols (having thick mollic horizon) in SW Poland are believed to be relatively young Holocene soils, which development was possible due to the 
human-driven large scale forest clearing and soil drainage. Consequently that created conditions for shrinking-swelling phenomena and formation of vertic horizons, as well as to the development of thick chernozemic horizons.

\section{ACKNOWLEDGEMENT}

The research was financially supported by Wrocław University of Environmental and Life Sciences, project No B030/0019/18. We are grateful to Aleksandra Loba and Martina Vogtli for their support during field-work and Krzysztof Kula for allowing access to sampling locality.

\section{REFERENCES}

Ahmad N., 1996. Occurrence and distribution of Vertisols. Developments in Soil Science 24: 1-41.

Badura J., Jary Z., Smalley I., 2013. Sources of loess material for deposits in Poland and parts of Central Europe: The lost Big River. Quaternary International 296: 15-22.

Bronk Ramsey C., 2009. Bayesian analysis of radiocarbon dates. Radiocarbon 51: 337-360.

DeCarlo K.F., Caylor K.K., 2019. Biophysical effects on soil crack morphology in a faunally active dryland vertisol. Geoderma 334: $134-145$.

IUSS Working Group WRB, 2015. World Reference Base for Soil Resources 2014, update 2015. International soil classification system for naming soils and creating legends for soil maps. World Soil Resources Reports, 106.

Góźdź S., 1957. Soils of the experimental station of the Institute of Plant Cultivation, Fertilization and Soil Science in Dobrogostów (Gleby zakładu naukowo-badawczego Instytutu Uprawy Nawożenia i Gleboznawstwa w Dobrogostowie). Master thesis, manuscript, WSR, Wrocław: 42 (in Polish).

Jary Z., Kida J., Śnihur M., 2002. Loess and loess-derived sediments in south-western Poland. Czasopismo Geograficzne 73(1-2): 63-100.

Kabała C., Bekier J., Binczycki T., Bogacz A., Bojko O., Cwielag-Piasecka I., Debicka M., Cuske M., Gałka B., Gersztyn L., Glina B., Jamroz E., Jezierski P., Karczewska A., Kaszubkiewicz J., Kawałko D., Kierczak J., Kocowicz A., Krupski M., Woźniczka P., 2015a. Soils of Lower Silesia. Polish Society of Soil Science, Polish Society of Humic Substances, Wrocław: 2-253.

Kabala C., Plonka T., Przekora A., 2015b. Vertic properties and gilgai-related subsurface features in soils of south-western Poland. Catena 128: 95-107.

Kabała C., Karczewska A., 2018. Methods of soil and plant analysis (Metodyka analiz laboratoryjnych gleb i roślin). Uniwersytet Przyrodniczy, Wrocław: 48 pp. (in Polish)

Kabała C., Charzyński P., Chodorowski J., Drewnik M., Glina B., Greinert A., Hulisz P., Jankowski M., Jonczak J., Łabaz B., Łachacz A., Marzec M., Mendyk Ł., Musiał P., Musielok Ł., Smreczak B., Sowiński P., Szymański W., Świtoniak M., Uzarowicz Ł., Waroszewski J. 2019a. Polish Soil Classification, 6th edition - principles, classification scheme and correlations. Soil Science Annual 70(2): 71-97.
Kabała C., Przybył A., Krupski M., Łabaz B., Waroszewski J., $2019 b$. Origin, age and transformation of Chernozems in northern Central Europe - new data from Neolithic earthen barrows in SW Poland. Catena 180: 83-102.

Khitrov N.B., Rogovneva L.V., 2014. Vertisols and vertic soils of the middle and lower Volga regions. Eurasian Soil Science 47(12): 1167-1186.

Kondracki J., 2002. Geografia regionalna Polski, Wydawnictwo Naukowe PWN, Warszawa: 216-222.

Kovda I., Goryachkin S., Lebedeva M., Chizhikova N., Kulikov A., Badmaev N., 2017. Vertic soils and Vertisols in cryogenic environments of southern Siberia, Russia. Geoderma 288: 184-195.

Kovda I.V., Wilding L.P., 2004. Vertisols: problems of classification, evolution and spatial self-organization. Eurasian Soil Science 37(12): 1341-1351.

Kural S., Jerzmański J., 1957. Explanations to Detailed Geological Map of the Sudeten Mountians (Objaśnienia do Szczegółowej Mapy Geologicznej Sudetów, arkusz Strzelin 1:25 000). Instytut Geologiczny, Warszawa: 55 pp.

Łabaz B., Kabała C., 2014. Origin, properties and classification of black earths in Poland (Geneza, właściwości i klasyfikacja czarnych ziem w Polsce). Soil Science Annual 65(2): 80-90.

Łabaz B., Kabała C., Waroszewski J., 2019. Ambient geochemical baselines for trace elements in Chernozems - approximation of geochemical soil transformation in an agricultural area. Environmental Monitoring and Assessment 191(1): 19.

Miller W.L., Kishne A.S., Morgan C.L., 2010. Vertisol morphology, classification, and seasonal cracking patterns in the Texas Gulf coast prairie. Soil Horizons 51(1): 10-16.

Mocek A., Owczarzak W., Tabaczyński R., 2009. Particle-size distribution and clay fraction mineralogy in black earths of Gniew (Uziarnienie oraz skład mineralogiczny frakcji ilastej czarnych ziem Gniewskich). Soil Science Annual - Roczniki Gleboznawcze 60(3): 123-132.

Moustakas N.K., 2012. A study of Vertisol genesis in North Eastern Greece. Catena 92: 208-215.

Nordt L.C., Wilding L.P., Lynn W.C., Crawford C.C., 2004. Vertisol genesis in a humid climate of the coastal plain of Texas, USA. Geoderma 122(1): 83-102.

Orzechowski M., Smólczyński S., Długosz J., Pozniak P., 2014. Measurements of texture of soils formed from glaciolimnic sediments by areometric method, pipette method and laser diffraction method. Soil Science Annual 65(2): 72-79.

Owczarzak W., Rząsa S., Kaczmarek Z., 1993. Shrinkage determination of soil aggregates. International Agrophysics 7(4): 221-227.

Pal D.K., Wani S.P., Sahrawat K.L., 2012. Vertisols of tropical Indian environments: pedology and edaphology. Geoderma 189: 28-49.

Pawlak W., Pawlak J., 2008. Atlas of the Lower and Opole Silesia. Wydawnictwo Uniwersytetu Wrocławskiego: 225 pp.

Pierre T. J., Primus A. T., Simon B. D., Hamadjida G., Monique A., Pierre N. J., Lucien B. D., 2018. Characteristics, classification and genesis of vertisols under seasonally contrasted climate in the Lake Chad Basin, Central Africa. Journal of African Earth Sciences 150: 176-193.

Polskie Towarzystwo Gleboznawcze, 2009. Klasyfikacja uziarnienia gleb i utworów mineralnych - PTG 2008 (Particle size distribution and textural classes of soils and mineral materials classification of Polish Society of Soil 
Science 2008). Roczniki Gleboznawcze - Soil Science Annual 60(2): 5-16.

Prusinkiewicz Z., 2001. Smolnice of Gniew - properties, origin, classification (Smolnice gniewskie - właściwości, geneza, systematyka). Roczniki Gleboznawcze - Soil Science Annual 52(1-2): 5-21.

Reimer P. J., Bard E., Bayliss A., 2013. IntCal13 and Marine13 radiocarbon age calibration curves $0-50,000$ years cal BP. Radiocarbon 55(4): 1869-1887.

Sánchez-Rodríguez A.R., del Campillo M.C., Torrent J., 2017. Phosphorus reduces the zinc concentration in cereals potgrown on calcareous Vertisols from southern Spain. Journal of the Science of Food and Agriculture 97(10): 3427-3432.

Sotelo-Ruiz E.D., Gutiérrez Castorena M. D. C., Ortiz Solorio C. A., 2013. Physical, chemical, and mineralogical characterization of Vertisols to determine their parent material. Interciencia, 38(7): 488-495.
Syers J. K., de Vries F. P., Nyamudeza P., 2001. The sustainable management of vertisols. Cabi International 20: 139-140.

Polish Soil Classification (Systematyka Gleb Polski), 2011. Roczniki Gleboznawcze - Soil Science Annual 62(3): 1-193. (in Polish with English summary).

Waroszewski J., Sprafke T., Kabala C., Musztyfaga E., Łabaz B., Woźniczka P., 2018. Aeolian silt contribution to soils on mountain slopes (Mt. Ślęża, southwest Poland). Quaternary Research 89(3): 702-717.

Waroszewski J., Sprafke T., Kabała C., Kobierski M., Kierczak J., Musztyfaga E., Loba A., Mazurek R., Łabaz B., 2019. Tracking textural, mineralogical and geochemical signatures in soils developed from basalt-derived materials covered with loess sediments (SW Poland). Geoderma 337: 983-997.

Uggla H., Witek T., 1958. Black earths of Kętrzyn (Czarne ziemie kętrzyńskie). Zeszyty Naukowe Wyższej Szkoły Rolniczej w Olsztynie 3: 69-108 Received: May 8, 2019

Received: May 8, 2019

Accepted: August 5, 2019

Associated editor: W. Szymański

\section{Właściwości i klasyfikacja wertisoli w warunkach zróżnicowania utworów macierzystych w rejonie Strzelina (SW Polska)}

Streszczenie: Wertisole to gleby charakteryzujące się wysoką zawartością frakcji iłowej, która przekłada się bezpośrednio na ich morfologię i właściwości fizyczne. Zdolności do cyklicznego kurczenia się i pęcznienia minerałów ilastych, w naprzemiennie występujących porach suchych i wilgotnych, powodują powstawanie w tych glebach głębokich szczelin, wrzecionowatych agregatów i gładkich powierzchni ślizgu na powierzchniach agregatów. W przeszłości uważano, że wertisole występują głównie w strefie tropikalnej lub subtropikalnej i do tej pory nie wykazywano ich obecności w umiarkowanym klimacie środkowej Europy. W efekcie wertisole nie zostały wystarczająco przebadane i opisane w Polsce, w tym na Dolnym Śląsku. Celem niniejszej pracy była analiza gleb ilastych występujących w rejonie Strzelina ze szczególnym uwzględnieniem ich morfologii, właściwości i klasyfikacji. Wykazano, że gleby wytworzone z neogeńskich iłów mają poziomu diagnostyczne vertic i mollic, którym towarzyszą właściwości gleyic lub stagnic. Jednakże nie wszystkie gleby spełniają kryteria wertisoli ze względu na obecność powierzchniowych lub podpowierzchniowych poziomów o grubszym uziarnieniu. Stwierdzono, że głównymi czynnikami decydującymi o przestrzennej mozaice wertisoli i czarnych ziem są różnicowanie materiału macierzystego oraz procesy geomorfologiczne.

Stowa kluczowe: wertisole, czarnoziemy, czarne ziemie, klasyfikacja gleb, mollic, iły 